\title{
Three new species of Pbaneros Kazantsev, 1992, with taxonomic notes and a key to Phaneros sensu stricto (Coleoptera: Lycidae)
}

\author{
Три новых вида Phaneros Kazantsev, 1992, с таксономическими \\ замечаниями и определительной таблицей Pbaneros sensu stricto \\ (Coleoptera: Lycidae)
}

\author{
Sergey V. Kazantsev \\ С.В. Казанцев
}

Insect Centre, Donetskaya 13-326, Moscow 109651, Russia.

Инсект-центр, ул. Донецкая 13-326, Москва 109651, Россия. E-mail: kazantss@mail.ru

KEY WORDS: Coleoptera, Lycidae, new species, taxonomy, Afrotropical region.

КЛЮЧЕВЫЕ СЛОВА: Coleoptera, Lycidae, новые виды, таксономия, Афротропическая область.

ABSTRACT. Three new species, Phaneros (s.str.) elgonensis, Ph. (s.str.) eurus and Ph. (s.str.) vespertinus spp.n. are described from, respectively, Uganda, Tanzania and Equatorial Guinea. Phaneros caffer (Kleine, 1933 ) is transferred from Phaneros (s.str.) to Phaneros (Kleineria) Kazantsev, 2004 as Phaneros (Kleineria) caffer (Kleine, 1933), comb.n. and Lectotype of Stadenus caffer Kleine, 1933 is designated. A key to Phaneros sensu stricto is provided and all seven known species of the subgenus are illustrated.

РЕЗЮМЕ. Описывается три новых вида, Phaneros (s.str.) elgonensis, Ph. (s.str.) eurus и Ph. (s.str.) vespertinus spp.n. из, соответственно, Уганды, Танзании и Экваториальной Гвинеи. Phaneros caffer (Kleine, 1933) переносится из Phaneros (s.str.) в Phaneros (Kleineria) Kazantsev, 2004 как Phaneros (Kleineria) caffer (Kleine, 1933), comb.n., и обозначается лектотип Stadenus caffer Kleine, 1933. Приводится определительная таблица Phaneros sensu stricto, а также иллюстрации всех семи известных видов подрода.

\section{Introduction}

The taxon Phaneros Kazantsev, 1992 was established for a group of African members of the Australian genus Stadenus Waterhouse, 1878 [Kazantsev, 1992]. Later on the subtribe Flagraxini was erected for the Afrotropical representatives of Dictyopterini [Kazantsev, 2004]. In 2006 Phaneros along with the other Afrotropical dictyopterines was reviewed and a key to its species was presented [Kazantsev, 2006]; at that time eight species were known in the genus, with five attributed to the nominative subgenus.

The Phaneros species seem to be quite rare, as only few specimens appear to be deposited in major museum collections, and differentiation criteria between them not quite clear. So the access to additional small series of Phaneros species collected recently in different places, and a careful re-examination of the material already at hand made it possible to clarify to some extent the relationships between the existing taxa. As a result, certain taxonomic changes appeared to be necessary and three species turned out to be yet undescribed. The description of these new to science species, as well as the taxonomic notes are given below, with all the members of the subgenus illustrated, and an identification key to all its species provided.

\section{Material and Methods}

The studied specimens were pinned or glued on cardboard plates. For a detailed examination they were relaxed in water; then the detached ultimate abdominal segments were treated for several hours in $10 \% \mathrm{KOH}$ at room temperature, then, with the extracted genitalia, placed in microvials with glycerin.

MSP-1 zoom stereoscopic dissecting microscope with $\mathrm{x} 8-\mathrm{x} 80$ magnification range was used. Photographs were taken with Canon EOS 6D camera and Canon MP-E 65 $\mathrm{mm}$ lens.

The following acronyms are used in the paper: ICM — Insect Center, Moscow; NHML — Natural History Museum, London; ZIW - Zoological Institute, Warsaw.

\section{Taxonomy}

Erotinae Leconte, 1881

Dictyopterini Houlbert, 1922

type genus: Dictyoptera Latreille, 1829.

Flagraxina Kazantsev, 2004

type genus: Flagrax Kazantsev, 1992.

Phaneros Kazantsev, 1992

Phaneros Kazantsev, 1992: 42.

type species: Stadenus xanthopterus Bourgeois, 1908. 
BIOLOGY. No preimaginal forms have been observed or collected in Phaneros sensu stricto. Imagines of the genus were collected in mountain forests at elevations up to $3500 \mathrm{~m}$ above sea level: Ph. (s.str.) xanthopterus (Bourgeois, 1908) - at 2000-3500 $\mathrm{m}$ in the forest zone of Kilimanjaro, Ph. (s.str.) elgonensis sp.n. - at $2200 \mathrm{~m}$ on slopes of Mount Elgon, Ph. (s.str.) inapicalis (Pic, 1928) - at 1800 and $2100 \mathrm{~m}$ near Lake Kivu and at 1800-2100 m in Nyungwe Forest in Rwanda. The lowest altitudes these beetles have been registered are $1150 \mathrm{~m}$ in the Democratic Republic of the Congo (Gorges de la Pelenge), where specimens of Ph. (s.str.) nigricollis (Pic, 1946) were collected, and $1000 \mathrm{~m}$ in East Usambara Mountains in Tanzania, where the type series of $P h$. (s.str.) eurus sp.n. was taken.

DISTRIBUTION. Phaneros is known from several places in West Africa and in the mountains of East Africa, from Uganda and Kenya to Transvaal in South Africa. The nominative subgenus has been reported both from western and eastern Africa, but not from South Africa (Fig. 22).

REMARKS. Phaneros is distinguished from other Flagraxina genera by the structure of antennomere 3 , which is short and similar in length and vestiture to antennomere 2 (e.g., Figs 2, 6), by mostly square elytral cells and the structure of the aedeagus with parameres fused to median lobe (e.g., Figs 3-4, 7-8). Phaneros is divided into three subgenera, Phaneros s.str., Bourgeoisiella Kazantsev, 1992 and Kleineria Kazantsev, 2004.

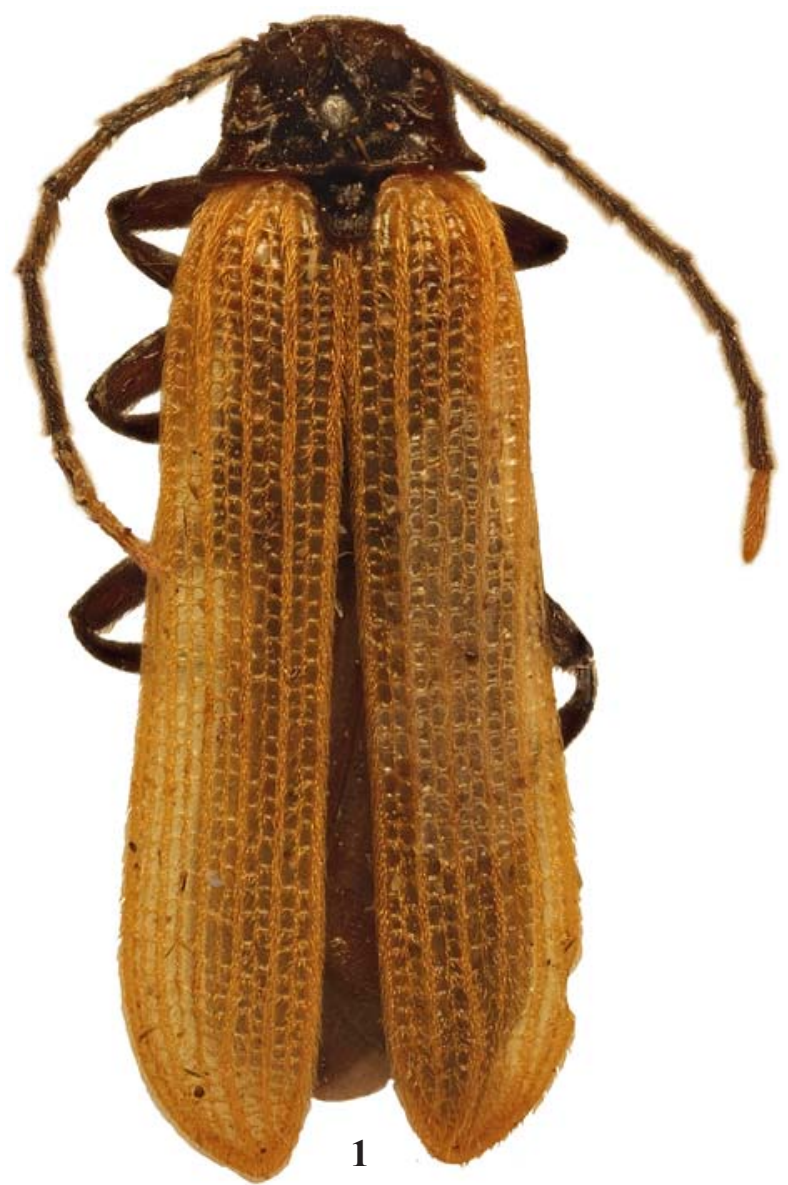

Phaneros (s.str.) Kazantsev, 1992

Phaneros (s.str.) Kazantsev, 1992: 42.

type species: Stadenus xanthopterus Bourgeois, 1908.

Phaneros (s.str.) elgonensis Kazantsev sp.n. Figs 1-4.

MATERIAL: Holotype, $\bigcirc^{7}$, Uganda: Mt. Elgon, northern slope, 2200 m, 14.X.1971, [coll. N. Drozdov] (ICM).

DESCRIPTION. Male. Black; antennomere 11 and elytra testaceous.

Vertex shining, with shallow transverse impression behind antennal prominence. Eyes small, interocular distance ca. 2 times greater than eye diameter. Labrum transverse, well sclerotised, densely punctate, anteriorly concave. Ultimate palpomeres conspicuously widened distally, oblique, flattened and glabrous at apex. Mandibles small, abruptly inwardly bent. Antennal sockets separated by short minute lamina. Antennae attaining to elytral three fourths, narrow, nearly filiform; antennomere 3 subequal in length and width to antennomere 2 and ca. 4 times shorter than antennomere 4 ; pubescence short and semi-erect (Figs 1-2).

Pronotum transverse, ca. 1.7 times wider than long, bisinuate posteriorly and straight anteriorly, with nearly parallel sides, acute narrow posterior and evident anterior angles; with diamond-shaped, relatively broad median areole, closed both anteriorly and posteriorly; lateral transverse carinae
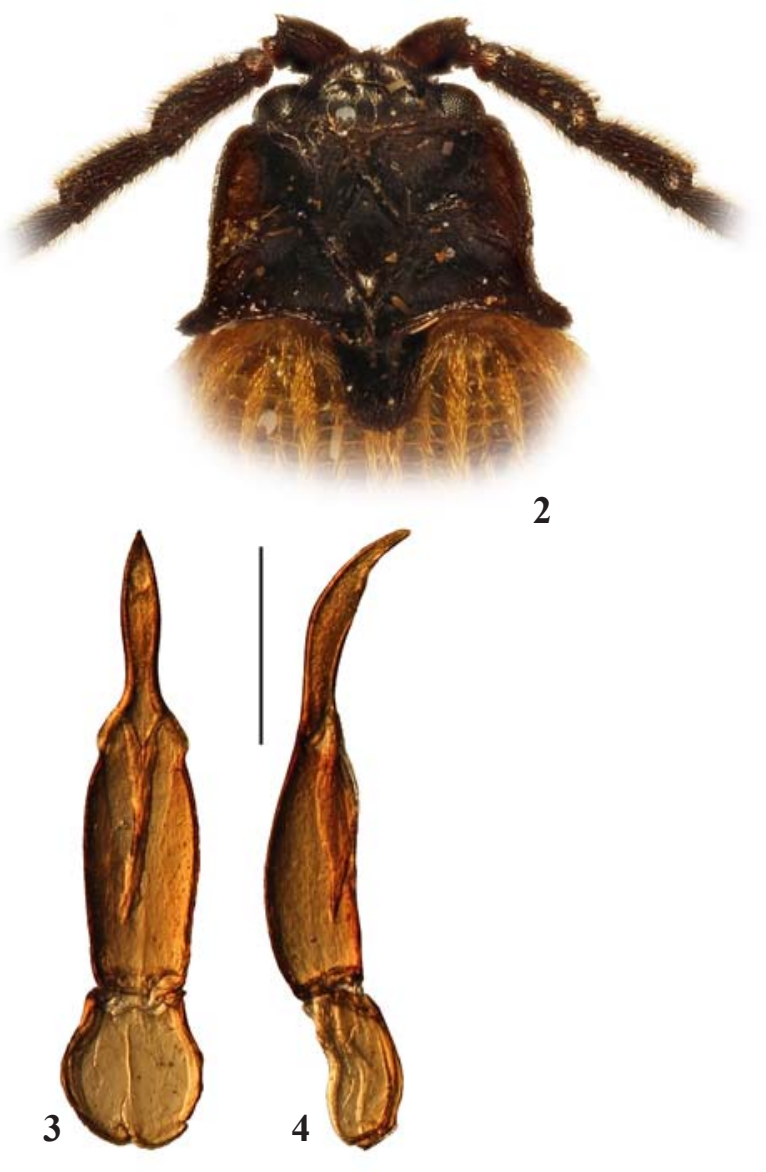

2

Figs 1-4. General view and details of Phaneros (s.str.) elgonensis sp.n., holotype male: 1 - general view; 2 - head and pronotum; 3 4 - aedeagus; 1, 2 - dorsal aspect; 3 - ventral aspect; 4 - lateral aspect. Scale bar: $0.5 \mathrm{~mm}$.

Рис. 1-4. Общий вид и детали строения Phaneros (s.str.) elgonensis sp.n., голотип, самец: 1 - общий вид; 2 - голова и переднеспинка; 3-4 - эдеагус; 1, 2 - сверху; 3 - снизу; 4 - сбоку. Масштабная линейка: 0.5 мм. 
complete, conspicuously curved; pubescence short and decumbent. Mesothoracic spiracle hoodless, oval at apex, not protruding beyond coxa. Scutellum elongate, narrowed distally, rounded at apex (Fig. 2).

Elytra long, ca. 3 times longer than wide at humeri, parallel-sided, with prominent primary costae; interstices with regular double rows of small, mostly elongate cells; pubescence along costae relatively dense and decumbent. Femoris straight, relatively broad, tibiae narrow, somewhat curved near base; tarsomeres 3-4 slightly widened, tarsomeres 3 and 4 combined subequal in length to tarsomere 5 and ca. 1.4 times longer than tarsomere 2; tarsomeres 1 and 2 with apical plantar pad (Fig. 1).

Ultimate ventrite elongate, with long, slightly asymmetric spiculum gastrale; spiculum gastrale subequal in length to ventrite. Aedeagus elongate, with oval, pointed apically, outwardly bent median lobe; parameral tube relatively narrow, slightly oval; length ratio of median lobe to parameral tube ca. $8.5: 10$; phallobase with incomplete median suture and shallow bilobed ventral incision (Figs 3-4).

Female. Unknown.

Length: $7.8 \mathrm{~mm}$. Width (humerally): $2.1 \mathrm{~mm}$.

ETYMOLOGY. The new species is named after Mount Elgon, its type locality.

DIAGNOSIS. Phaneros elgonensis sp.n. is apparently close to Ph. napicalis, distinguishable by the more elongate cells of the elytral reticulation (Fig. 1) and shorter and more oval median lobe of the aedeagus (Figs 3-4).

\section{Phaneros (s.str.) eurus Kazantsev sp.n.}

Figs 5-8.

MATERIAL: Holotype, $0^{7}$, Tanzania: East Usambara, Amani N.R., $1000 \mathrm{~m}, 5.05^{\circ} \mathrm{S}, 38.40^{\circ} \mathrm{E}, 20-22 . I .2010$, M. Mityukhin leg. (ICM); paratype, + , same label (ICM).

DESCRIPTION. Male. Black; head, three basal antennomeres, antennomere 9 distally, antennomeres 10-11, palps,
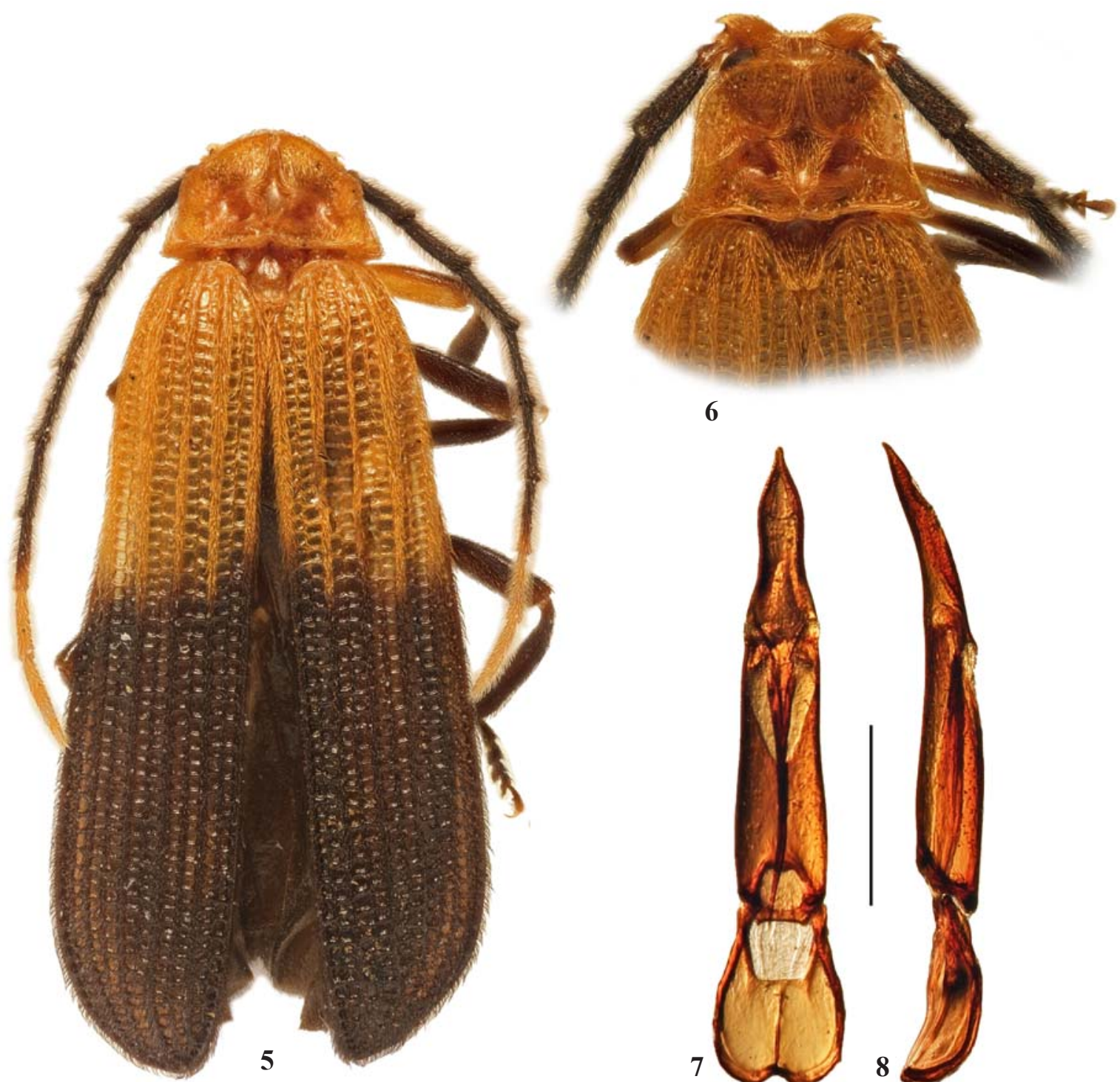

6

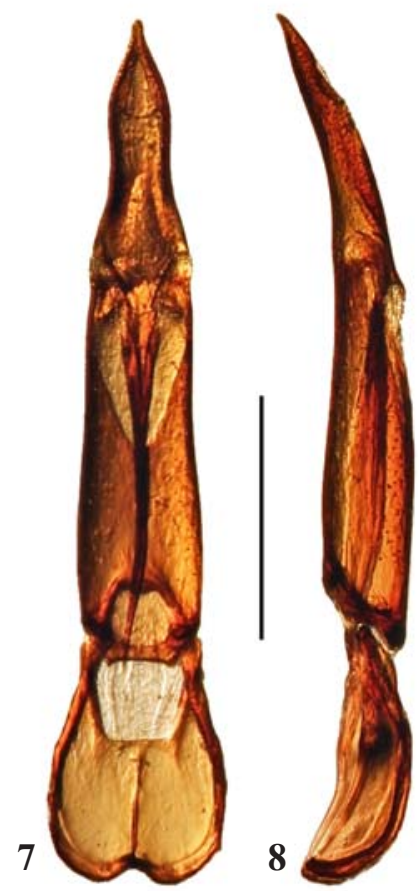

Figs 5-8. General view and details of Phaneros (s.str.) eurus sp.n., holotype male: 5 - general view; 6 - head and pronotum; 7-8 aedeagus; 5, 6- dorsal aspect; 7 - ventral aspect; 8 - lateral aspect. Scale bar: $0.5 \mathrm{~mm}$.

Рис. 5-8. Общий вид и детали строения Phaneros (s.str.) eurus sp.n., голотип, самец: 5 - общий вид; 6 - голова и переднеспинка; 7-8 - эдеагус; 5, 6 - сверху; 7 - снизу; 8 - сбоку. Масштабная линейка: 0.5 мм. 
except ultimate palpomeres, pronotum, scutellum, prosternum, mesoventrite, elytra, except at distal three fifths, trochanters, front femoris and middle femoris proximally orange testaceous (Figs 5-6).

Vertex shining, with round impression behind antennal prominence. Eyes small, interocular distance ca. 2 times greater than eye diameter. Labrum short, transverse, well sclerotised, anteriorly concave. Ultimate palpomeres widened distally, oblique, flattened and glabrous at apex. Mandibles small, abruptly inwardly bent. Antennal sockets separated by short minute lamina. Antennae attaining to elytral three fourths, narrow, almost filiform; antennomere 3 subequal in length and width to antennomere 2 and ca. 4 times shorter than antennomere 4; pubescence short and erect (Figs 5-6).

Pronotum transverse, ca. 1.6 times wider than long, feebly bisinuate posteriorly and slightly convex anteriorly, with almost parallel sides, acute narrow posterior and blunt rounded anterior angles; with diamond-shaped, relatively broad median areole, closed both anteriorly and posteriorly; lateral transverse carinae complete, conspicuously curved; pubescence short and decumbent. Mesothoracic spiracle hoodless, flattened at apex, short, not protruding beyond coxa. Scutellum elongate, narrowed distally, rounded and minutely medially notched at apex (Fig. 6).

Elytra long, 2.9 times longer than wide at humeri, inconspicuously widened distally, with prominent primary costae;
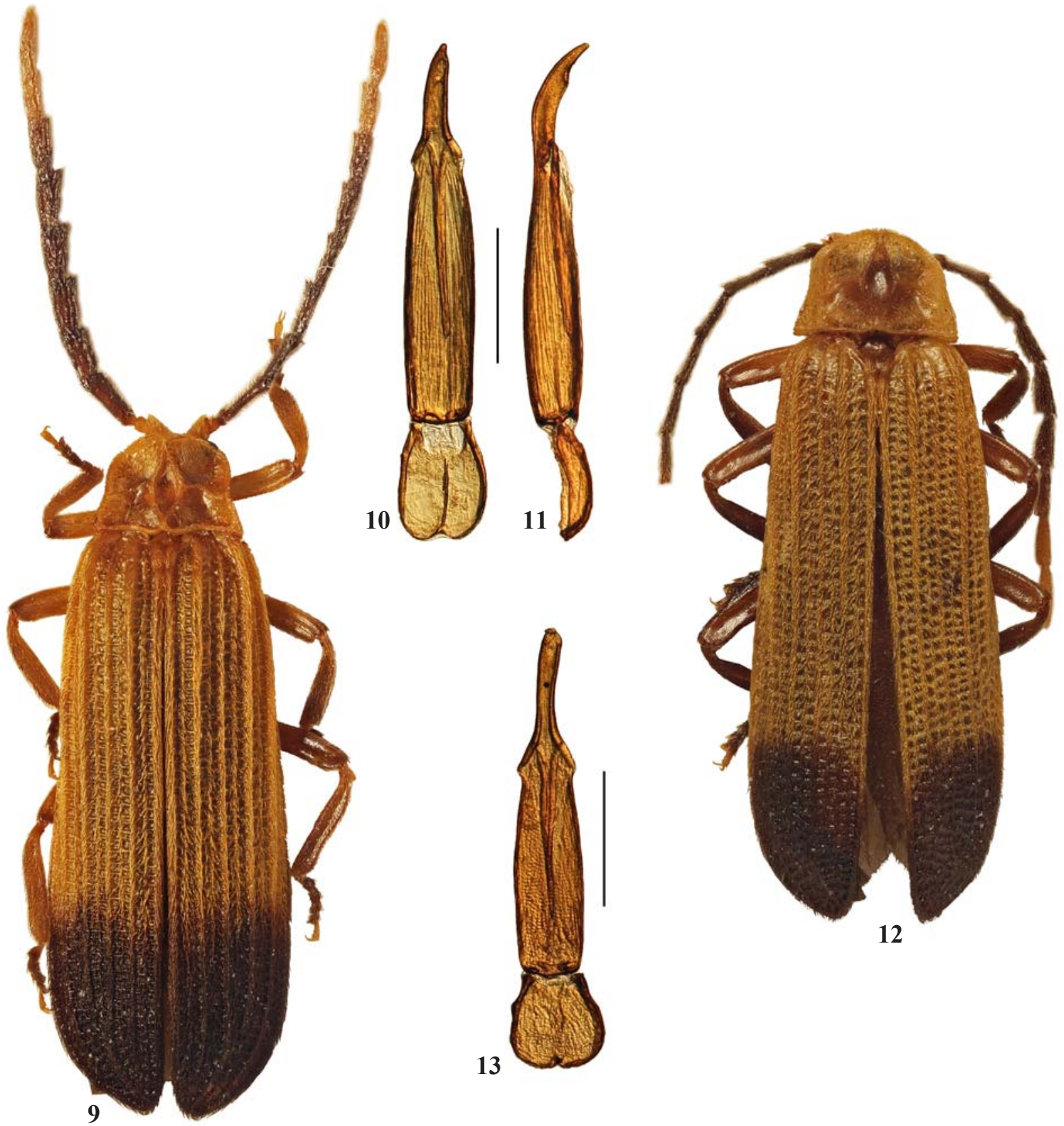

Figs 9-13. General view and details of Phaneros (s.str.) species, males: 9-11 - Ph. (s.str.) vespertinus sp.n., holotype; 12-13 - Ph. (s.str.) costatus. 9, 12 - general view; 10-11, 13 - aedeagi; 9, 12 - dorsal aspect; 10, 13 - ventral aspect; 11 - lateral aspect. Scale bar: 0.5 mm. Рис. 9-13. Общий вид и детали строения видов Phaneros (s.str.), самцы: 9-11 - Ph. (s.str.) vespertinus sp.n., голотип; 12-13 - Ph. (s.str.) costatus. 9, 12 - общий вид; 10-11, 13 - эдеагус; 9, 12 - сверху; 10, 13 - снизу; 11 - сбоку. Масштабные линейки: 0.5 мм. 
interstices with regular double rows of roundish cells; pubescence along costae relatively dense and decumbent. Femoris and tibiae straight, relatively narrow; tarsomeres 3-4 slightly widened, tarsomeres 3 and 4 combined subequal in length to tarsomere 5 and ca. 1.4 times longer than tarsomere 2; tarsomeres 1 and 2 with apical plantar pad (Fig. 5).

Ultimate ventrite elongate, with long asymmetric spiculum gastrale; spiculum gastrale slightly longer than ventrite. Aedeagus elongate, with long, narrow, pointed apically, inwardly bent median lobe, parameral tube almost parallelsided, with apparent deep incision at base in dorsal aspect; length ratio of median lobe to parameral tube ca. $5.5: 10$; phallobase with complete median suture and deep trapezoidal ventral incision (Figs 7-8).

Female. Unknown.

Length: $8.0-8.7 \mathrm{~mm}$. Width (humerally): $2.3-2.4 \mathrm{~mm}$.

ETYMOLOGY. The name of the new species is derived from the Latin for "eastern", alluding to the distribution pattern of the species.

DIAGNOSIS. Phaneros eurus sp.n. may be distinguished from other Phaneros sensu stricto species by the black distal three fifths of elytra (Fig. 5), inwardly bent median lobe, apparent deep dorsal incision at the base of parameral tube and deeper ventral incision in the phallobase of the aedeagus (Figs 7-8).

\section{Phaneros (s.str.) vespertinus Kazantsev sp.n.} Figs 9-11.

MATERIAL: Holotype, $\sigma^{\top}$, EQUATORIAL GUINEA: Evinayong, 1974, A. Petrov leg. (ICM).

DESCRIPTION. Male. Orange testaceous; antennomeres 3-9, palpomeres, elytral distal third, metaventrite, abdomen and tarsi, except tarsomere 5, black (Fig. 9).
Vertex shining, with shallow roundish impression behind antennal prominence. Eyes small, interocular distance ca. 2 times greater than eye diameter. Labrum short, transverse, well sclerotised, anteriorly concave. Ultimate palpomeres slightly widened distally, oblique, flattened and glabrous at apex. Mandibles small, abruptly inwardly bent. Antennal sockets separated by short minute lamina. Antennae attaining to elytral two thirds, moderately dentate; antennomere 3 subequal in length and width to antennomere 2 and ca. 4.9 times shorter than antennomere 4; pubescence short and semi-erect (Fig. 9).

Pronotum transverse, ca. 1.5 times wider than long, trapezoidal, with slightly concave sides, acute posterior and rounded anterior angles; anteriorly semicircularly produced forward, bisinuate at posterior margin; with oval, relatively broad median areole, closed both anteriorly and posteriorly; lateral transverse carinae complete, noticeably curved. Mesothoracic spiracle small, hoodless, not protruding beyond coxa. Scutellum elongate, slightly narrowed distally, medially notched at apex (Fig. 9).

Elytra long, 3 times longer than wide at humeri, almost parallel-sided, with prominent primary costae; interstices with regular double rows of mostly transverse cells; pubescence along costae dense and decumbent. Femoris and tibiae straight, relatively narrow; tarsomere 4 feebly widened, tarsomeres 3 and 4 combined ca. 1.2 times shorter than tarsomere 5 and ca. 1.2 times longer than tarsomere 2 ; tarsomeres 1 and 2 with minute apical plantar pad (Fig. 9).

Ultimate ventrite elongate, with long symmetric spiculum gastrale; spiculum gastrale noticeably longer than ventrite. Aedeagus elongate, with relatively short, narrow, pointed apically, outwardly bent median lobe, parameral tube
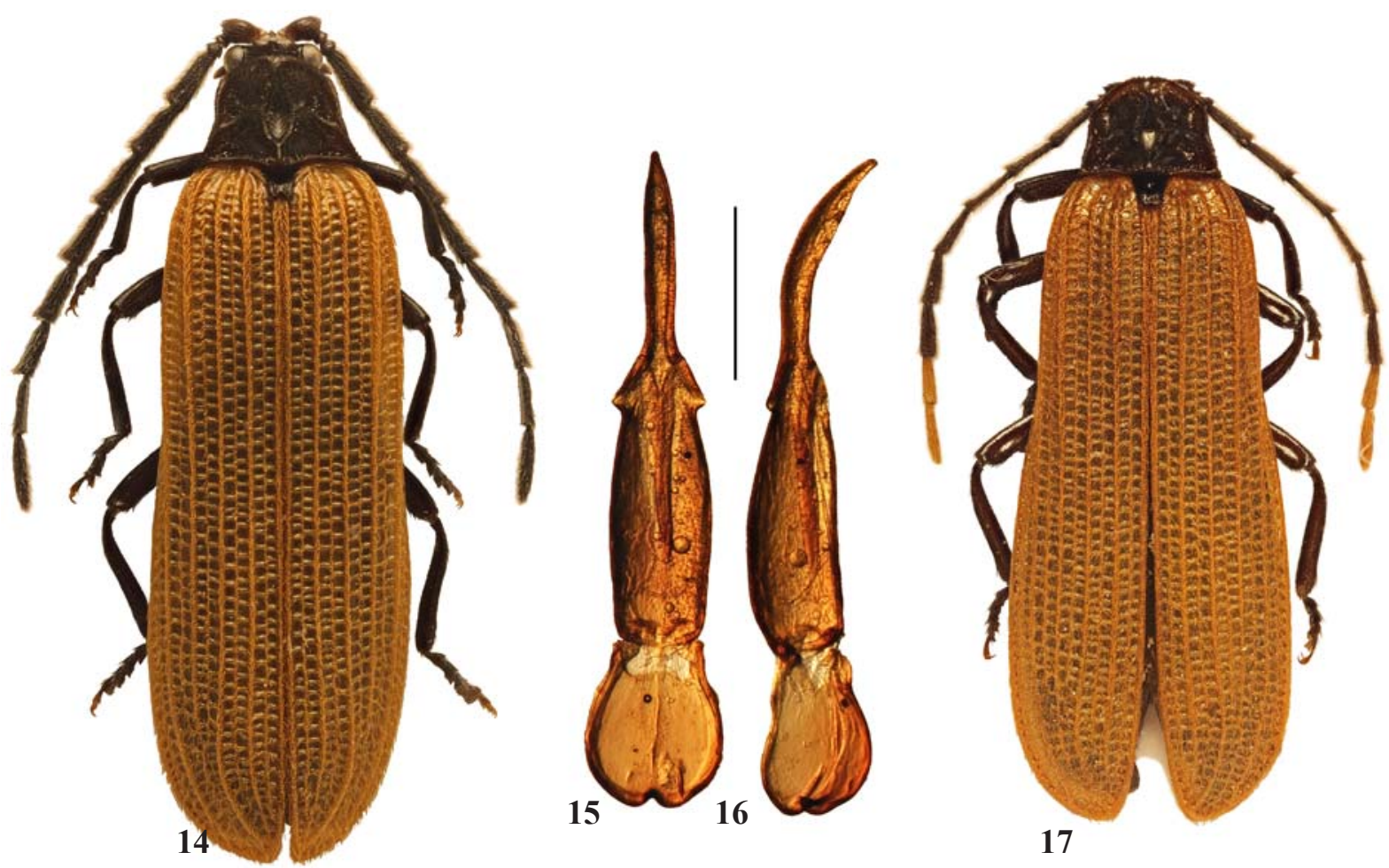

Figs 14-17. General view and details of Phaneros (s.str.) inapicalis, males. 14, 17 - general view; 15-16 — aedeagus; 14, 17 - dorsal aspect; 15 - ventral aspect; 16 - lateral aspect. Scale bar: $0.5 \mathrm{~mm}$.

Рис. 14-17. Общий вид и детали строения видов Phaneros (s.str.) inapicalis, самцы. 14, 17 — общий вид; 15-16 — эдеагус; 14, 17 - сверху; 15 - снизу; 16 - сбоку. Масштабная линейка: 0.5 мм. 
almost parallel-sided, without incision at base dorsal aspect; length ratio of median lobe to parameral tube ca. 4.5 : 10; phallobase with complete median suture and deep rectangular ventral incision (Figs 10-11).

Female. Unknown.

Length: $7.8 \mathrm{~mm}$. Width (humerally): $2.1 \mathrm{~mm}$.

ETYMOLOGY. The name of the new species is derived from the Latin for "western", alluding to the distribution pattern of the species.

DIAGNOSIS. Phaneros vespertinus sp.n. has apparently to be placed near Ph. costatus, distinguishable by the long and nearly parallel-sided parameral tube of the aedeagus (Figs 10-11).

\section{Phaneros (s.str.) costatus (Pic, 1915)} Figs 12-13.

Stadenus costatus Pic, 1915: 12

DISTRIBUTION. Cameroon, Gabon, Equatorial Guinea.

REMARKS. The reanalysis of the available material identified as Phaneros costatus demonstrates that the series actually consists of two species. There are two male specimens: in one of them, which more accurately corresponds to the female Lectotype in coloration, the distal part of aedeagus is noticeably longer, constituting ca. 0.7 of its parameral part (Fig. 13), vs ca. 0.4 in the other (Figs 10-11). This male is considered to represent the true $P h$. costatus, while the other, differing in coloration of legs, whose aedeagus was erroneously illustrated as that of $P h$. costatus in one of the previous papers (Kazantsev, 2006), is considered to represent $P h$. vespertinus sp.n.

Phaneros (s.str.) inapicalis (Pic, 1928)

Figs 14-17.

Stadenus inapicalis Pic, 1928: 61.

= Stadenus incrassicornis Pic, 1946: 6 .

DISTRIBUTION. Uganda, eastern Congo.

REMARKS. Phaneros inapicalis is represented by two colour variations, one with uniformly black antennae, the other with testaceous two ultimate antennomeres (Figs 14, 17). Both forms were taken at one location in Rwanda (Nyungwe N.P., 1800-2000 m, 3-16.VII.2014, Sv. Kurbatova leg.).

Phaneros (s.str.) nigricollis (Pic, 1946)

Fig. 18

Stadenus nigricollis Pic, 1946: 6.

DISTRIBUTION. Eastern Congo.

REMARKS. Phaneros nigricollis does not differ from $P h$. inapicalis other than in coloration of distal third of the elytra, their aedeagi being identical (Figs 15-16). Although their female external genitalia seem to be somewhat different [Kazantsev, 2006] and transitional forms have not been reported, it is possible that these two taxa are conspecific.
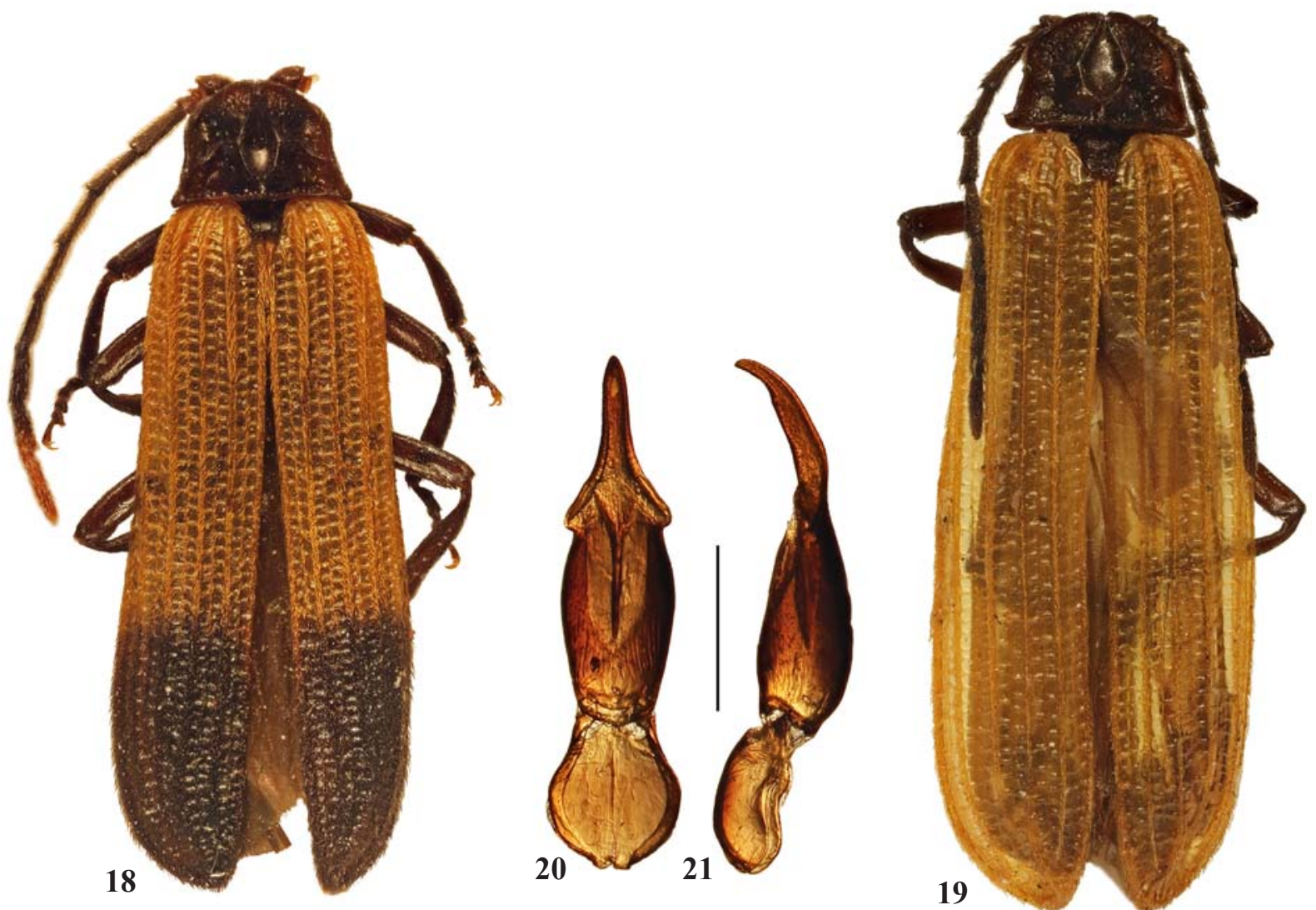

Figs 18-21. General view and details of Phaneros (s.str.) species: 18 - Ph. (s.str.) nigricollis; 19-21 - Ph. (s.str.) xanthopterus; 18, 20-21 - males; 19 - female. 18-19 - general view; 20-21 — aedeagus; $18-19$ - dorsal aspect; 20 - ventral aspect; 21 - lateral aspect. Scale bar: $0.5 \mathrm{~mm}$.

Рис. 18-21. Общий вид и детали строения видов Phaneros (s.str.): 18 - Ph. (s.str.) nigricollis; 19-21 - Ph. (s.str.) xanthopterus; 18, 20-21 - самцы; 19 - самка. 18-19 - общий вид; 20-21 - эдеагус; 18-19 - сверху; 20 - снизу; 21 - сбоку. Масштабная линейка: 0.5 мм. 
Phaneros (s.str.) xanthopterus (Bourgeois, 1908) Figs 19-21.

Stadenus xanthopterus Bourgeois, 1908: 274.

DISTRIBUTION. East Africa (Kenya, Tanzania).

REMARKS. Phaneros (s.str.) xanthopterus (Bourgeois, 1908), quite easily separable from the congeners by the shape of the aedeagus (Figs 20-21), seems to be restricted to the forested slopes of Mounts Kilimanjaro and Kenya [Kazantsev, 1992].

A key to the SPecies of Phaneros Sensu stricto

1. Aedeagus broad (Figs 20-21)

Ph. (s.str.) xanthopterus (Bourgeois)

- Aedeagus relatively narrow (e.g., Figs 3-4, 7-8, 10-11,
13)

2

2. Distal three fifths of elytra black (Fig. 5). Median lobe of aedeagus inwardly bent, parameral tube deeply incised dorsal aspect at base and ventral opening in phallobase deep (Figs 7-8) ....................... Ph. (s.str.) eurus sp.n.

- At most distal third of elytra black (Fig. 18). Median lobe of aedeagus outwardly bent, parameral tube not incised dorsal aspect at base and ventral opening in phallobase shallow (e.g., Figs 4, 8) .

3. Pronotum orange testaceous, distal third of elytra black (Fig. 9). Parameral tube of aedeagus long, more than 2 times longer than median lobe (Figs 10-11)

$P h$. (s.str.) vespertinus sp.n.

- Parameral tube of aedeagus shorter (Figs 3-4, 13, 15-16, 20-21)

4

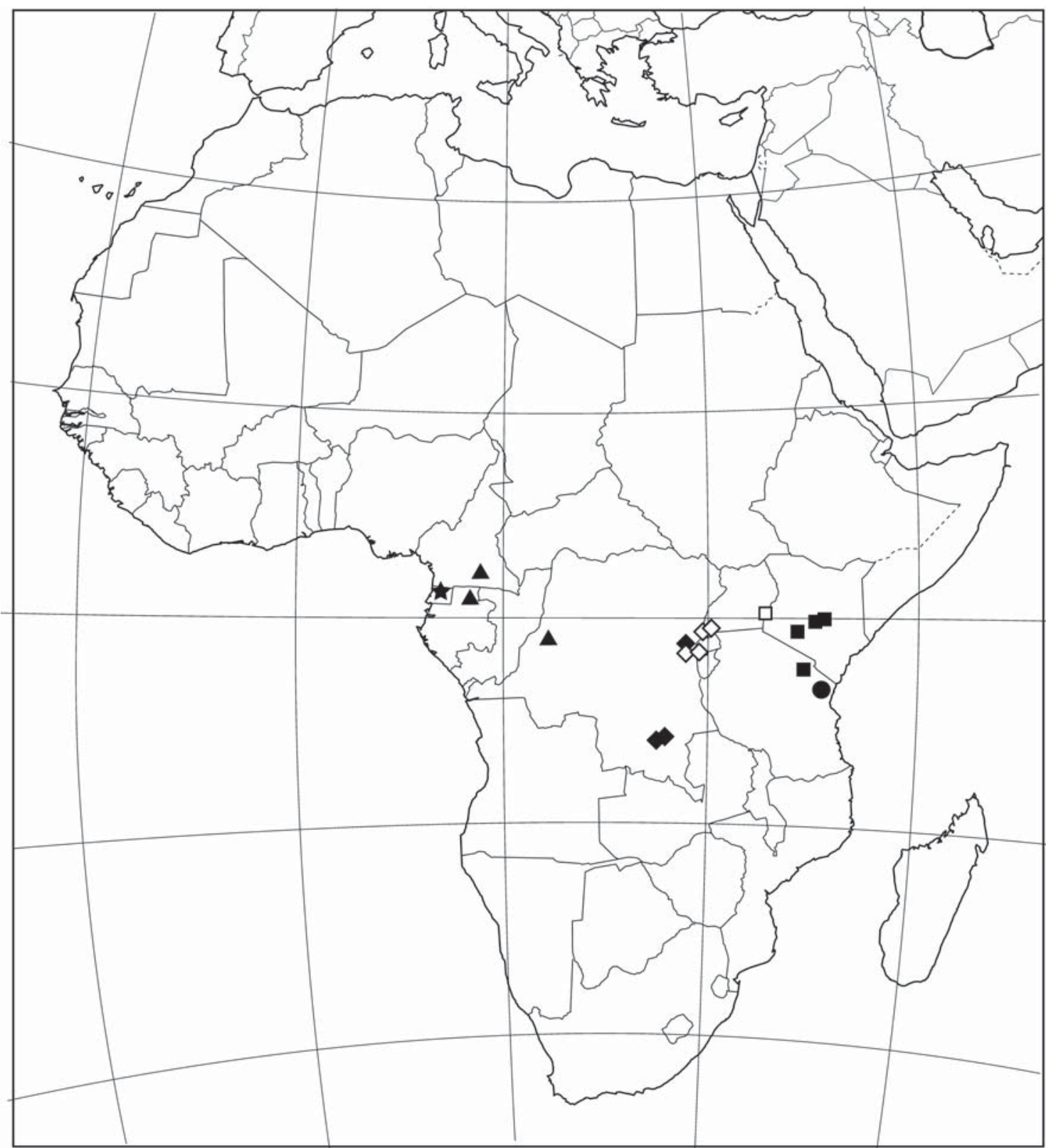

Fig. 22. Distribution of Phaneros (s.str.) species: $\mathbf{\Delta}-$ Ph. (s.str.) costatus; $\square-P h$. (s.str.) elgonensis sp.n.; $\bigcirc$ - Ph. (s.str.) eurus sp.n.; $\star — P h$. (s.str.) vespertinus sp.n.; $\square-P h$. (s.str.) xanthopterus; $\diamond-P h$. (s.str.) inapicalis; $\bullet-P h$. (s.str.) nigricollis.

Рис. 22. Распространение видов Phaneros (s.str.): $\boldsymbol{\Delta}$ - Ph. (s.str.) costatus; $\square-P h$. (s.str.) elgonensis sp.n.; - Ph. (s.str.) eurus sp.n.; $\star-P h$. (s.str.) vespertinus sp.n.; $\square-P h$. (s.str.) xanthopterus; $\diamond-P h$. (s.str.) inapicalis; $\bullet-P h$. (s.str.) nigricollis. 
4. Elytral reticulation cells mostly elongate (Fig. 1). Median lobe of aedeagus relatively short, noticeably oval (Figs 3 4) Ph. (s.str.) elgonensis sp.n.

- Elytral reticulation cells mostly transverse (Figs 12, 14, 15). Median lobe of aedeagus relatively long, nearly parallel-sided (Figs 13, 15-16)

5. Pronotum testaceous (Fig 12). Length ratio of med lobe to parameral tube ca. 7 : 10 (Fig. 13)

Ph. (s.str.) costatus

- Pronotum black (Figs 14, 17, 18). Median lobe subequal in length to parameral tube (Figs 15-16)

6. Elytra uniformly testaceous (Figs 14, 17)

Ph. (s.str.) inapicalis (Pic)

- Distal third of elytra black (Fig. 18)

$$
\text { Ph. (s.str.) nigricollis }
$$

Phaneros (Kleineria) caffer (Kleine, 1933), comb.n.

Stadenus caffer Kleine, 1933: 4.

Phaneros (s.str.) caffer: Kazantsev, 1992; 2006.

DISTRIBUTION. South Africa and Malawi.

REMARKS. Stadenus caffer was described from a series that included one male and four females from three localities: [South Africa: Eastern Cape], Port St. John, Pondoland; [South Africa]: Zululand, Eshowe and [Malawi]: Nyasaland: Mlanje; Shire Valley, with the types deposited in the British Museum (now Natural History Museum, London) [Kleine, 1933]. The drawing of the aedeagus given for Phaneros caffer was taken from a presumed paratype male of Stadenus caffer from the Kleine collection in the Zoological Institute, Warsaw (ZIW) from «Nyasaland, Mlanje» [Kazantsev, 1992].

However, the photograph of the male syntype of Stadenus caffer from Port St. John, Pondoland, the locality mentioned first by Kleine [1933] and deposited at the Natural History Museum in London (https://www.flickr.com/photos/ nhm_beetle_id/32663318256/in/album-72157676466189423/), demonstrates that this taxon does not belong in Phaneros sensu stricto, due to the equally raised at base primary elytral costae and noticeably longer antennomeres 2 and 3, and should probably be referred to the subgenus Kleineria. The NHML male from Port St. John, Pondoland is hereby designated Lectotype of Stadenus caffer, and the taxon is tentatively transferred to the subgenus Kleineria as Phaneros (Kleineria) caffer (Kleine, 1933), comb.n.

The ZIW collection specimen, which cannot be considered for designation as Lectotype of Stadenus caffer, due to the fact that the place of deposition of the types of the taxon is the British Museum and there is just one male specimen in the type series [Kleine, 1933], appears to be not conspecific with Ph. (Kl.) caffer (Kleine, 1933), comb.n.

ACKNOWLEDGEMENTS. It is my pleasant duty to express gratitude to Dr. Dariusz Iwan (Zoological Institute of the Polish Academy of Sciences, Warsaw) for the opportunity to study the Kleine collection under his care. My special thanks are due to Ms. Svetlana Kurbatova and Dr. Sergey Kurbatov (Moscow) for the interesting additional Phaneros material collected during their entomological expedition to Rwanda and to Dr. Michael Geiser and Dr. Keita Matsumoto (Natural History Museum, London) for providing info on and photographs of the syntypes of Stadenus caffer.

\section{References}

Kazantsev S.V. 1992. Revision of the genus Stadenus (Coleoptera, Lycidae) of Africa // Russian Entomological Journal. Vol.1. No.1. P.37-50.

Kazantsev S.V. 2004. Phylogeny of the tribe Erotini (Coleoptera, Lycidae), with descriptions of new taxa // Zootaxa. Vol.496. P.1-48.

Kazantsev S.V. 2006. A review and phylogenetic analysis of Afrotropical Dictyopterini (Coleoptera, Lycidae) // Mitteilungen aus dem Museum für Naturkunde in Berlin, Deutsche Entomologische Zeitschrift. B.53. H.1. S.43-64.

Kleine R. 1933. Neue Lyciden und Bemerkungen zum Cat. Col. Junk-Schenkling Lycidae // Stettiner Entomologische Zeitung. Bd.94. H.1. S.1-20. 